\title{
The Long and Winding Road to a European Higher Education Area
}

\section{Hans de Wit}

Hans de Wit is vice-president for international affairs at the University of Amsterdam and editor of the Journal of Studies in International Education. Address: Universiteit van Amsterdam, Spui, Amsterdam, Netherlands. E-mail: <hansdw@bdu.uva.nl>.

$\mathrm{T}$ he Bologna Declaration of June 19, 1999 was the start of a process that will lead to the creation of a European higher education area. The Bologna Declaration had six objectives: comparable degrees, a two-cycle degree structure, establishment of a course credit system, and promotion of mobility and common European patterns in higher education. These objectives need to be accomplished by 2010, the final completion date of the European higher education area.

The Declaration is supported by 32 European ministers of education. University leaders and students have also welcomed-although with different emphases and interpretations-the plans for a new European higher education area. The Bologna Declaration was based on a 1998 initiative drawn up at the Sorbonne, Paris, by the ministers of education of the four large countries: Germany, France, Italy, and the United Kingdom. At the time there was immediate wide support for this ambitious reform plan, but also skepticism about the prospects for realization. (See the author's article in the Winter 2001 issue of IHE.)

In May 2001, the ministers of education met in Prague to discuss the progress to date; the group was joined by ministers from Croatia, Cyprus, and Turkey. It was clear that while there remains a long road ahead most countries, although at varying speeds, are working on the implementation of the objectives. According to the report, Trends in Learning Structures in Higher Education II, prepared by Guy Haug and Christian Taugh for the Prague meeting, there is general consensus on the core objectives of the Bologna process and fears about the process seem to be rapidly diminishing. The process confirms and reinforces national priorities and is being used to accelerate, facilitate, and guide changes in the different countries. The report states that "the Bologna process is both a consequence of and a contribution to the process of integration of European higher education."

Much of the attention after the Bologna meeting was focused on the implementation of a two-tier degree system. Several countries are working on the system-for instance, Italy and the Netherlands, where new enabling legislation has been put in place. At the Prague meeting the emphasis appeared to have shifted to the importance of quality assurance, recognition issues, and accreditation. In the communiqué issued after the meeting, the ministers stressed the quality of education and research as crucial issues in the realization of the European higher education area. The ministers also agreed on the importance of enhancing the attractiveness of European higher education to students from Europe and other parts of the world. The readability and comparability of European higher education degrees worldwide should be promoted by the development of a common framework of qualifications, as well as by coherent quality assurance and accreditation or certification mechanisms and increased information efforts. The follow-up work to the Prague meeting, in preparation for the 2003 talks in Berlin, will focus particularly on these types of issues. The challenge will be whether institutions of higher education in Europe will be able to cross regional and national boundaries to become players in the European and global higher education market. Helmut de Rudder, in a spring 2000 contribution to this newsletter, described a provincial and rather immobile European higher education sector, but one certainly on the way to becoming more European. His optimism is quite broadly shared.

The Salamanca Convention of European higher education institutions, organized by the European University Association (EUA) in March 2001, welcomed and supported the emergence of the European higher education area and the challenges of operating in a competitive environment. The EUA was created when two organizations in European higher education merged in 2000: the Association of European Universities and the Confederation of EU Rectors' Conferences. At the same time, the institutions pointed to the importance of maintaining as guiding principles the autonomy of higher education; higher education as a public, rather than a commercial, good; and its diversity in terms of languages, systems, types, profiles, and curricular orientation. Quality assurance, compatible qualifications, and attractiveness are seen as crucial elements for the realization of the new European higher education space.

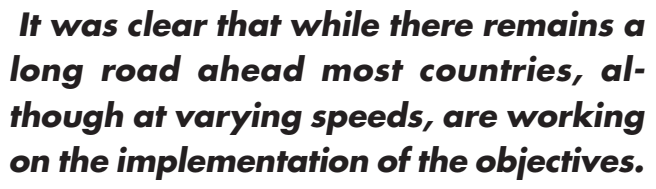

As stated in the Salamanca convention document: "European higher education institutions recognise that their students need and demand qualifications which they can 
effectively use for the purpose of study and career all over Europe. The institutions and their networks and organisations acknowledge their role and responsibility in this regard and confirm their willingness to organise themselves accordingly within the framework of autonomy."

Students themselves did make their voices heard directly. In March 2001, the National Unions of Students in Europe (ESIB) organized an event in Götenborg, Sweden, and were successful in presenting their views at the Prague meeting in May. In the "Student Götenborg Declaration," the students declare that they see the Bologna process as a crucial step toward a European higher education area. At the same time, the students demand guarantees that all citizens will have equal access to this area, regardless of their social background. Expanded mobility, higher quality, and increased attractiveness are seen as the important assets that the Bologna process will yield for students, but these must coincide with adequate funding for study grants and for higher education institutions. The national unions of students have demanded via ESIB an active role as the process unfolds.

Both the institutions and the students seem to have been heard by the ministers at the Prague meeting, given the emphasis placed on the students' issues in the communiqué. The close cooperation between ministers, institutions, and students in the realization of the European higher education area, is probably the most striking aspect of the Bologna process and crucial for its success. At the same time, keeping all parties involved and focused ensures that the process will be a long and complex one; Berlin is the next stop on the way to 2010 .

Note: Texts of the Bologna Declaration, the Prague communiqué, and the Trends reports are to be found on several European websites. The most complete collection of documents on the Bologna process can be found at <http://www.salamanca2001.org.>

\section{Manuel Castells and the Information Age \\ Peter Scott}

Peter Scott is vice chancellor of Kingston University, UK. Address: Vice Chancellor, Kingston University, River House, 53-57 High Street. Kingston upon Thames, Surrey KT1 1LQ, UK. E-mail: <p.scott@kingston.ac.uk>.

Manuel Castells, The Information Age: Economy, Society and Culture. Vol. 1: The Rise of the Network Society (1996; 2d ed., 2000), 594 pp.; vol. 2: The Power of Identity (1997; 2d ed., 2000), 460 pp.; vol. 3: End of Millennium (1998; 2d ed., 2000), 448 pp. Oxford: Blackwell, price: \$27.95. £16.99 each.

$\mathrm{M}$ anuel Castells' trilogy on the Information Age, first published between 1996 and 1998, was a phenomenon-a publishing phenomenon for the simple reason that it become a best-seller demanding frequent reprints-and an intellectual phenomenon because Castells was delicately poised on the cusp between impenetrable theorizing and breathless popularizing. It is only a little unfair to say that he took the work of people like Alain Touraine and Anthony Giddens and packaged it for the audience of Tom Peters or Charles Handy.

Two of the three books have now been revised-the first, on the rise of what Castells calls the Network Society, because of the accumulation (and acceleration) of relevant data, most of which incidentally tends to confirm his broad thesis; and the third, in which Castells speculates about a new postmillennial social order, because recent events may have detracted from the power and persuasiveness of his original analysis. The second, on the reconstruction of personal identity, new social movements, and the crisis of the nation state, has remained unchanged. But it could be argued that this volume too required revision, not least be- cause the essentially benign social movements of the 1960 s (with which Castells aligns himself in personal, if not intellectual, terms) have tended to be pushed aside by the much more aggressive activism of campaigns against globalization, GM foods, animal experimentation, and the rest.

Castells' ambition was to develop an empirically grounded, cross-cultural sociological theory of the Information Age. It was a grand ambition, in which he largely succeeded. Certainly no one can complain about a lack of data; indeed there is almost too much at times. This is both a strength and a weakness - a strength because just occasionally social theorizing is unencumbered by empirical data, which makes effective critique difficult; but a weakness because much of Castells' data, inevitably, are highlevel aggregations by national statistical agencies or from the OECD, World Bank, UNESCO, and similar organizations, which raises issues of both accuracy and comparative methodology. What he offers is very much a macroview of social and economic development, which creates difficulties because much of his analysis emphasizes the importance of interstitial, even intimate, cultural change.

Nor can anyone complain about the global reach of Castells' analysis. His is not a frustratingly parochial midAtlantic view of the world, a NATO-ist perspective in which North America and Western Europe (and their outliers) still represent the cutting-edge, the Future. He pays as much attention, inevitably, to East Asia (once rampant, even tri- 